Pacific Journal of Mathematics

CORRECTION TO: "COMMUTANTS OF SOME HAUSDORFF 
Proposition A. Let $V$ be a valuation ring having a proper prime ideal $P$ which is not branched; then $P=\bigcup_{\lambda \in A} M_{\lambda}$, where $\left\{M_{\lambda}\right\}_{\lambda \in A}$ is the collection of prime ideals of $V$ which are properly contained in $P$. In this case, $P \cdot V[[X]]=P[[X]]$ if and only if $(*)$ given any countable subcollection $\left\{M_{\lambda_{i}}\right\}$ of $\left\{M_{\lambda}\right\}, \bigcup_{i=1}^{\infty} M_{\lambda_{i}} \subset P$.

Proof. Assuming (*), let $f(X)=\sum_{i=0}^{\infty} f_{i} X^{i} \in P[[X]]$. For each $i$, $f_{i} \in M_{\bar{\lambda}_{i}}$ for some $\bar{\lambda}_{i} \in \Lambda$. Let $p \in P, p \notin \bigcup_{i=0}^{\infty} M_{\bar{\lambda}_{i}}$; since $p \notin M_{\bar{\lambda}_{i}}$, it follows that $f_{i} \in M_{\bar{\lambda}_{i}} \subseteq(p) V$ for each $i$ and $f(X) \in(p) V[[X]] \subseteq P \cdot V[[X]]$.

Conversely, assuming that $\left(^{*}\right)$ fails, let $\left\{M_{\lambda_{i}}\right\}_{i=1}^{\infty}$ be a countable subcollection of $\left\{M_{\lambda}\right\}_{\lambda \in A}$ such that $\bigcup_{i=1}^{\infty} M_{\lambda_{i}}=P$. By extracting a subsequence of $\left\{M_{\lambda_{i}}\right\}$, we may assume that $M_{\lambda_{i}} \subset M_{\lambda_{i+1}}$ for each $i$. Let $f_{i} \in M_{\lambda_{i+1}}, f_{i} \notin M_{\lambda_{i}}$ and let $f(X)=\sum_{i=1}^{\infty} f_{i} X^{i}$; then $f(X) \in P[[X]]$ but $f(X) \notin P \cdot V[[X]]$.

MARSHALL UNIVERSITY

Correction to

\section{COHOMOLOGY OF FINITELY PRESENTED GROUPS}

P. M. Curran

Volume 42 (1972), 615-620

In the second paragraph of the abstract, p. 615 , the first sentence, "If $G$ is generated by $n$ elements, ..." should read "If $G$ is a residually finite group generated by $n$ elements, ...".

Correction to

COMMUTANTS OF SOME HAUSDORFF MATRICES

B. E. RHOADES

Volume 42 (1973), 715-719

In [2] it is shown that, for $A$ a conservative triangle, $B$ a matrix with finite norm commuting with $A, B$ is triangular if and only if

(1) for each $t \in l$ and each $n, t\left(A-a_{n n} I\right)=0$ implies $t$ belongs to the linear $\operatorname{span}$ of $\left(e_{0}, e_{1}, \cdots, e_{n}\right)$. On page 716 of [2] it is asserted that

(2) $\left(U^{*}\right)^{n+1}\left(A-a_{n n} I\right) U^{n+1}$ of type $M$ for each $n$ is equivalent to 
(1). This assertion is false. Condition (2) is sufficient for (1) but, as the following example shows, it is not necessary.

EXAMPLE 1. Let $A$ be a triangle with entries $a_{n k}=p_{n-k}$, $n, k=0,1, \cdots$, where $p_{k}=2^{-k}$. Then, for each $n, A-a_{n n} I=$ $\left(U^{*}\right)^{n+1}\left(A-a_{n n} I\right) U^{n+1}=B$, where $b_{n n}=0$ for each $n$, and $b_{n k}=a_{n k}$ otherwise. The only solutions of $t B=0$ for $t \in l$ lie in the linear span of $e_{0}$, so that $A$ satisfies (1). However, $B$ is not of type $M$.

Since (2) is not equivalent to (1), some of the material on pages 717 and 718 of [2] must now be reworked.

We establish the following facts:

1. If a factorable triangular matrix $A$ contains at least two zeros on the main diagonal, then $\operatorname{Com}(A)$ in $\Delta \neq \operatorname{Com} A$ in $\Gamma$.

2. If $A$ is not factorable, then the number of zeros on the main diagonal gives no information about the size of $\operatorname{Com}(A)$ in $\Gamma$.

3. Having distinct diagonal entries is necessary but not sufficient for a conservative Hausdorff matrix $H$ to satisfy $\operatorname{Com}(H)$ in $\Delta=$ $\operatorname{Com}(H)$ in $\Gamma$.

Proof of 1. Let $n$ and $k$ denote the smallest integers for which $a_{k k}=a_{n n}=0, n>k$. Then the system $t\left(A-a_{k k} I\right)=0$ clearly has a solution in the space spanned by $\left(e_{0}, e_{1}, \cdots, e_{n}\right)$. It remains to show that there is a solution not in the subspace spanned by $\left(e_{0}, e_{1}, \cdots, e_{k}\right)$. Since $A$ is factorable, either the $k$ th row or the $k$ th column of $A$ is zero. In either case we can obtain a solution of the system using $t_{n}=1, t_{k}=0$ for $k>n$, which can be used to construct a nontriangular conservative matrix $B$ which commutes with $A$.

Proof of 2. Define $D=\left(d_{n k}\right)$ by $d_{n 0}=1, d_{n k}=0$ otherwise. Then $D \leftrightarrow B$ implies that $(D B)_{n k}=b_{0 k}$, whereas $(B D)_{n 0}=\sum_{j} b_{n j}$, and $(B D)_{n k}=0$ for $k>0$. Thus, if $B$ is any matrix satisfying (i) $b_{0 k}=0$ for all $k>0$ and (ii) $\sum_{j=0}^{\infty} b_{n j}=b_{00}$ for all $n>0$, then $B \leftrightarrow D$. For example, if $b_{00}=1, b_{n k}=2^{n-k-1}, k \geqq n>0 \quad b_{n k}=0$ otherwise, then $B$ is row infinite and commutes with $D . \quad D$ is factorable, but $A=D+I$ is not. Moreover, since $\operatorname{Com}(I)$ in $\Gamma=\Gamma, \operatorname{Com}(A)$ in $\Gamma=\operatorname{Com}(D)$ in $\Gamma \neq \operatorname{Com}(D)$ in $\Delta$.

Example 1 with $p_{0}=0$ is a nonfactorable matrix with an infinite number of zeros on the main diagonal, and yet $\operatorname{Com}(A)$ in $\Gamma=\operatorname{Com}(A)$ in $\Delta$.

The following examples establish 3.

EXAMPLE 2. Let $H$ be the Hausdorff matrix generated by $\mu_{n}=$ $-2 n(n-1) /(n+1)(n+2), B=\left(b_{n k}\right)$ with $b_{0 k}=b_{1 k}=1$ for all $k, b_{n k}=0$ otherwise. Then $B \leftrightarrow H$, but $B \notin \Delta$ since $b_{01} \neq 0$. 
ExAMPLE 3. Let $H$ be generated by $\mu_{n}=n(n-1 / 2) /(n+1)(n+2)$. We can regard $H$ as the product of two Hausdorff matrices $H_{\alpha}$ and $H_{\beta}$, with generating sequences $\alpha_{n}=(n-1 / 2) /(n+1)$ and $\beta_{n}=n /(n+2)$, respectively. From Theorem 1 of [1], the sequence $t=\left\{t_{n}\right\}$, with $t_{0}=1, t_{n}=(-1)^{n}(1 / 2)(-3 / 2) \cdots(-n+3 / 2) / n !, n>0$ satisfies $t H_{\alpha}=0$. Therefore $t H=0$. Let $B$ be the matrix with the sequence $t$ as each row. Then

$$
(H B)_{n k}=\sum_{j=0}^{n} h_{n j} b_{j k}=t_{k} \sum_{j=0}^{n} h_{n j}=t_{k} \mu_{0}=0
$$

and

$$
(B H)_{n k}=\sum_{j=k}^{\infty} b_{n j} h_{j k}=\sum_{j=k}^{\infty} t_{j} h_{j k}=0, \quad \text { so that } B \longleftrightarrow H .
$$

\section{REFERENCES}

1. B. E. Rhoades, Some Hausdorff matrices not of type M, Proc. Amer. Math., Soc., 15 (1964), 361-365.

2. Commutants of some Hausdorff matrices, Pacific J. Math., 42 (1972), $715-719$.

INDIANA UNIVERSITY

Corrections to

\section{VERSUM SEQUENCES IN THE BINARY SYSTEM}

Charles W. Trigg

Volume 47 (1973), 263-275

Line 12 should read "the universal verity of the conjecture $[5,6]$ ". Instead of the universal verity of the conjecture $[1,2]$.

The first page should be 263 instead of 163. 



\section{PACIFIC JOURNAL OF MATHEMATICS}

\section{EDITORS}

RICHARD ARENS (Managing Editor)

University of California

Los Angeles, California 90024

\section{R. A. Beaumont}

University of Washington

Seattle, Washington 98105

\section{J. DuGundJI*}

Department of Mathematics

University of Southern California

Los Angeles, California 90007

D. Gilbarg and J. Milgram

Stanford University

Stanford, California 94305

ASSOCIATE EDITORS
E. F. BECKENBACH
B. H. NeumanN
F. WOLF
K. YoSHIDA

\section{SUPPORTING INSTITUTIONS}

UNIVERSITY OF BRITISH COLUMBIA

CALIFORNIA INSTITUTE OF TECHNOLOGY

UNIVERSITY OF CALIFORNIA

MONTANA STATE UNIVERSITY

UNIVERSITY OF NEVADA

NEW MEXICO STATE UNIVERSITY

OREGON STATE UNIVERSITY

UNIVERSITY OF OREGON

OSAKA UNIVERSITY

\author{
UNIVERSITY OF SOUTHERN CALIFORNIA \\ STANFORD UNIVERSITY \\ UNIVERSITY OF TOKYO \\ UNIVERSITY OF UTAH \\ WASHINGTON STATE UNIVERSITY \\ UNIVERSITY OF WASHINGTON \\ AMERICAN MATHEMATICAL SOCIETY \\ NAVAL WEAPONS CENTER
}

The Supporting Institutions listed above contribute to the cost of publication of this Journal, but they are not owners or publishers and have no responsibility for its content or policies.

Mathematical papers intended for publication in the Pacific Journal of Mathematics should be in typed form or offset-reproduced, (not dittoed), double spaced with large margins. Underline Greek letters in red, German in green, and script in blue. The first paragraph or two must be capable of being used separately as a synopsis of the entire paper. Items of the bibliography should not be cited there unless absolutely necessary, in which case they must be identified by author and Journal, rather than by item number. Manuscripts, in duplicate if possible, may be sent to any one of the four editors. Please classify according to the scheme of Math. Rev. Index to Vol. 39. All other communications to the editors should be addressed to the managing editor, or Elaine Barth, University of California, Los Angeles, California, 90024.

50 reprints are provided free for each article; additional copies may be obtained at cost in multiples of 50 .

The Pacific Journal of Mathematics is issued monthly as of January 1966. Regular subscription rate: $\$ 48.00$ a year (6 Vols., 12 issues). Special rate: $\$ 24.00$ a year to individual members of supporting institutions.

Subscriptions, orders for back numbers, and changes of address should be sent to Pacific Journal of Mathematics, 103 Highland Boulevard, Berkeley, California, 94708.

\section{PUBLISHED BY PACIFIC JOURNAL OF MATHEMATICS, A NON-PROFIT CORPORATION}

Printed at Kokusai Bunken Insatsusha (International Academic Printing Co., Ltd.), 270, 3-chome Totsuka-cho, Shinjuku-ku, Tokyo 160, Japan.

* C. R. DePrima California Institute of Technology, Pasadena, CA 91109, will replace J. Dugundji until August 1974.

Copyright (C) 1973 by

Pacific Journal of Mathematics

All Rights Reserved 


\section{Pacific Journal of Mathematics}

\section{Vol. 49, No. $2 \quad$ June, 1973}

Wm. R. Allaway, On finding the distribution function for an orthogonal polynomial

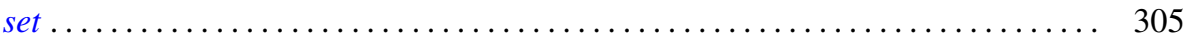

Eric Amar, Sur un théorème de Mooney relatif aux fonctions analytiques bornées... . 311

Robert Morgan Brooks, Analytic structure in the spectrum of a natural system . . . . 315

Bahattin Cengiz, On extremely regular function spaces . . . . . . . . . . . . . . 335

Kwang-nan Chow and Moses Glasner, Atoms on the Royden boundary . . . . . . . . . 339

Paul Frazier Duvall, Jr. and Jim Maxwell, Tame $Z^{2}$-actions on $E^{n} \ldots \ldots \ldots \ldots \ldots . .349$

Allen Roy Freedman, On the additivity theorem for $n$-dimensional asymptotic

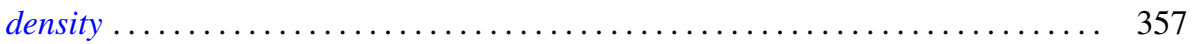

John Griffin and Kelly Denis McKennon, Multipliers and the group $L_{p}$-algebras . . . 365

Charles Lemuel Hagopian, Characterizations of $\lambda$ connected plane continua ....... 371

Jon Craig Helton, Bounds for products of interval functions . . . . . . . . . . . 377

Ikuko Kayashima, On relations between Nörlund and Riesz means . . . . . . . . . . 391

Everett Lee Lady, Slender rings and modules . . . . . . . . . . . . . . . . . . 397

Shozo Matsuura, On the Lu Qi-Keng conjecture and the Bergman representative



Stephen H. McCleary, The lattice-ordered group of automorphisms of an $\alpha$-set . . . 417

Stephen H. McCleary, o-2-transitive ordered permutation groups .......... 425

Stephen H. McCleary, o-primitive ordered permutation groups. II . . . . . . . . . 431

Richard Rochberg, Almost isometries of Banach spaces and moduli of planar

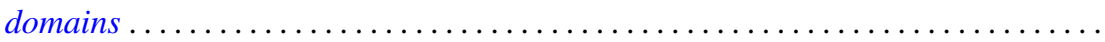

R. F. Rossa, Radical properties involving one-sided ideals . . . . . . . . . . . . . 467

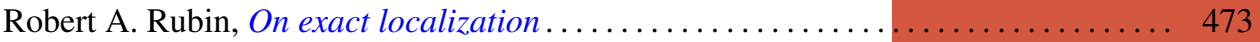

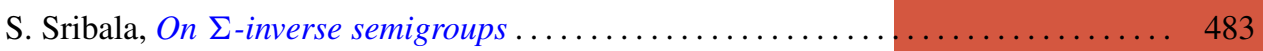

H. M. (Hari Mohan) Srivastava, On the Konhauser sets of biorthogonal polynomials suggested by the Laguerre polynomials ...................... 489

Stuart A. Steinberg, Rings of quotients of rings without nilpotent elements . ...... 493

Daniel Mullane Sunday, The self-equivalences of an $H$-space . . ............ 507

W. J. Thron and Richard Hawks Warren, On the lattice of proximities of $\check{C} e c h$

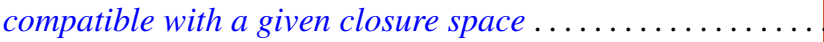

Frank Uhlig, The number of vectors jointly annihilated by two real quadratic forms determines the inertia of matrices in the associated pencil .

Frank Uhlig, On the maximal number of linearly independent real vectors annihilated simultaneously by two real quadratic forms ..............

Frank Uhlig, Definite and semidefinite matrices in a real symmetric matrix pencil . . 561

Arnold Lewis Villone, Self-adjoint extensions of symmetric differential operators . . . 569

Cary Webb, Tensor and direct products . ....................... 579

James Victor Whittaker, On normal subgroups of differentiable

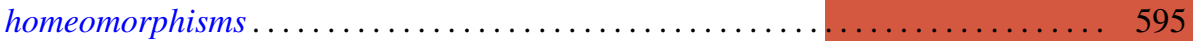

Jerome L. Paul, Addendum to: "Sequences of homeomorphisms which converge to

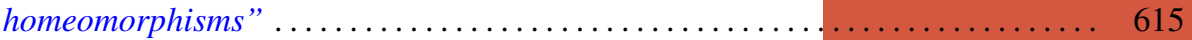

David E. Fields, Correction to: “Dimension theory in power series rings” ........ 616

Peter Michael Curran, Correction to: “Cohomology of finitely presented groups”. . . 617

Billy E. Rhoades, Correction to: “Commutants of some Hausdorff matrices” ...... 617

Charles W. Trigg, Corrections to: "Versum sequences in the binary system” ...... 619 